\title{
The Study on Bali Tourism Village Management towards Four Dimensions of Experience Economy
}

\author{
Widi Hardini, Ni Luh Putu Agustini Karta and Jimmy Harry Putu Suarthana
}

\author{
School of Postgraduate Study \\ Doctorate Degree in Tourism Udayana University \\ Coressponding author: widihardini@gmail.com
}

\begin{abstract}
ARTICLE INFO ABSTRACT
Received

24 November 2014

Accepted

26 February 2015

Available online

10 March 2015

Tourism as one of the largest industries in the world economy is now entering a new era, the experience economy. The concept adopted by Pine and Gilmore in 1998, where there was a shift in the company's economic orientation. This concept emphasizes the customer value and suitable in services industry, especially in Tourism industry. In the new economic era, customer satisfaction is no longer the main things, but delivering comprehensive services to create a memorable experience. Bali tourism industry focuses on cultural development and preservations. There is a linkage between the experience economy concept and tourism village concept, which is at the participation level of all components in the development (management, tourists and the society). Therefore, the concept of experience economy is suitable to be applied in the development of tourism villages. This research conducted to elaborate and analyze the classification of tourism village product and the levels of tourist participation towards four dimensions of experience economy concept. Through qualitative research methods will generate a depth understanding of managing tourism village by creating tourist memorable experience.
\end{abstract}

Keywords: experience economy, management, memorable experience, tourism village.

\section{Introduction}

\section{Background}

The purpose of a person travelling essentially is to gain the experience. In the context of cultural tourism, Richardson and Fluker (2004) stated that "one of the most compelling motivations for people to travel is to see how other people live and to learn something of their cultural heritage". A person who travels with cultural motivation will gain the cultural tourism experience from destination. Cultural tourism defined as "the movement of persons to cultural attractions away from their normal place of residence, with the intention to gather new information and experiences to satisfy their cultural needs" (Richards, 2007; cited in Leslie and Sigala, 2005).

http://ojs.unud.ac.id/index.php/eot
In the cultural management perspectives, it is important to fulfill the cultural needs of tourist through experience. Stasiak (2013) said that "experience is considered a new value and the main source of consumer satisfaction". Refer to cultural tourism understanding, de Cauter (1996; cited in Richards, 2001) argued that the most important motivation for visiting cultural sites is 'to experience new things', and the growth in cultural visitation can be interpreted as an attempt to satisfy the 'experience hunger' which characterizes late modern society. The management of cultural tourism destination should be able to meet the needs of cultural tourist by interpreting a proper cultural product at sites. Regardless of how sophisticated tourists' needs are, they always expect first of all a professionally prepared, all 
inclusive offer, which will meet their expectations (Stasiak, 2013). There is a shift paradigm of experience in the economy perspectives. According to Pine and Gilmore (1998), the economists have typically lumped experiences in with services, but experiences are a distinct economic offering, as different from services are from goods. The concept emphasizes the customer value and company's economic orientations. "Experience represent an existing but previously unarticulated genre of economic output" (Pine and Gilmore, 2011). In the new economic era, customer satisfaction is no longer the main things, but delivering comprehensive services to create a memorable experience.

Tourism village is a kind of cultural product implementation in tourism industry. It lays on the purpose, by interpreting the cultural heritage product at sites might create tourist experience and delivered the understanding of history and real live of community activities. Pine II and Gilmore (1999) argued that the economy has gone through a transition from extracting commodities to making goods, delivering services and currently staging experiences as the primary arena of value creation. The development of tourism village creates values among the stakeholders (especially for the local community) through economy and education. Cultural tourism has become a vital means of economic support for traditional activities and local creativity (Richards, 2007).

Picard (1996) stated that "culture is Bali's defining feature, and Balinese culture is renowned for its dynamic resilience". Bali is inseparable with its culture. Bali tourism industry focuses on cultural development and environment preservations. According to the regulations of Bali province about Bali cultural tourism, the implementation of cultural tourism development based on the diversity, uniqueness of Balinese culture and nature as well as the need for traveling (PERDA Bali Province, Act No.2. III. 5. 4, 2012). In the new economy era, it is important to develop a comprehensive cultural product presentation by involving the tourist participation in order to achieve a memorable experience.

http://ojs.unud.ac.id/index.php/eot
There are several numbers of Bali cultural tourism research (in particularly tourism village) based on sustainability development, community-based, tourist satisfaction and marketing strategy. Despite it there's not yet been found the approach of experience economy concept with tourism villages. Therefore, this research conducted to elaborate and analyze the classification of tourism village product and the levels of tourist participation towards four dimensions of experience economy concept. This research conducted in three Bali tourism village, Bedulu tourism village (Gianyar), Buahan tourism village (Bangli) and Taman Sari Buwana tourism village (Tabanan) based on previous research (continual case study).

\section{Literature Review}

Cultural tourism can be means as an experiential tourism, involved in and stimulated by a great variety of things such as, performing arts, visual arts, festivals, cuisines, history, experiencing nostalgia and other ways of life (Richardson and Fluker, 2004). The implementation of cultural tourism through tourism village concept can be seen as the way of gaining tourist experience. By the cultural tourism concept, (Richardson and Fluker, 2004) viewed essentially as an opportunity for tourist to experience, understand and appreciate the character of a place, its richness and diversity.

\section{Tourism Village Concept}

Tourism village is a formed of cultural heritage development through tourism. Besides exploring the culture and nature of destinations, it is an attempt to sustain the cultural heritage. Ardika (2011) defined tourism village as a journey in order to enjoy the atmosphere of rural life, gain the mutual respect and cultures, values, traditions and natural environment, results in a two-way learning process between tourist and community, and improve the welfare of rural communities. Within cultural tourism development in tourism village, there will be a commodification culture from its originality. It is the management effort or a way to interpret the cultural message for tourist. Nevertheless, the core cultural of the origin destination may remain authentic. There are three components 
in cultural tourism: travel, the tourist, and the sites (Tighe, 1991; cited in Leslie and Sigala, 2005).

\section{Experience Economy Concept}

There are two approaches within the experience economy concept, psychological (experience) and economical (economy). According to Ju (2014), the aims of experience economy concept is to maximize the pursuit of customer satisfaction, to obtain economic benefits by the customer profound personalized experience. The mutual benefits between company and customer achieve through the implementation of experience economy concept. Craven (1990:4; cited in Page et al., 2001) define economics as a study methods of allocating scare resources and distributing the product of those resources, and the study of the consequences of those methods of allocation and distribution. In order to define experience concept is by elaborating the characteristic. Boswijk et al. (2007; cited in Bille and Business, 2010) elaborate the characteristic of experience as: (1) a high degree of concentration and focus; (2) the involvement of all senses; (3) the perception of time is changed (made irrelevant); (4) one is affected emotionally; (5) the process is unique and has intrinsic value for the individual; (6) contact with "the real thing"; (7) one does and undergoes something; (8) there is an element and sense of play and expectation; (9) one feels in control of the situation; (10) there is a balance between the challenge and one's capacity to meet it; (11) there is a clear goal. The core concept of both understanding is at the process to create and deliver values. The intention of experience economy is equalize values of customer and company. In order to gain a deep understanding, Pine and Gilmore (1998) classified experience economy into four dimensions:

(1) Educational : Customer as an active participation tends to involved in the activities, but they're likely still more outside the event.

(2) Escapist

: Customer as an active participation tends to greater involvement in the activities (immerse).

(3) Esthetic : Customer as a passive participant immersed in the activities, but they have little or no effect on it.

(4) Entertainment : Customer as a passive participant, their connection to the event is more likely one of absorption.

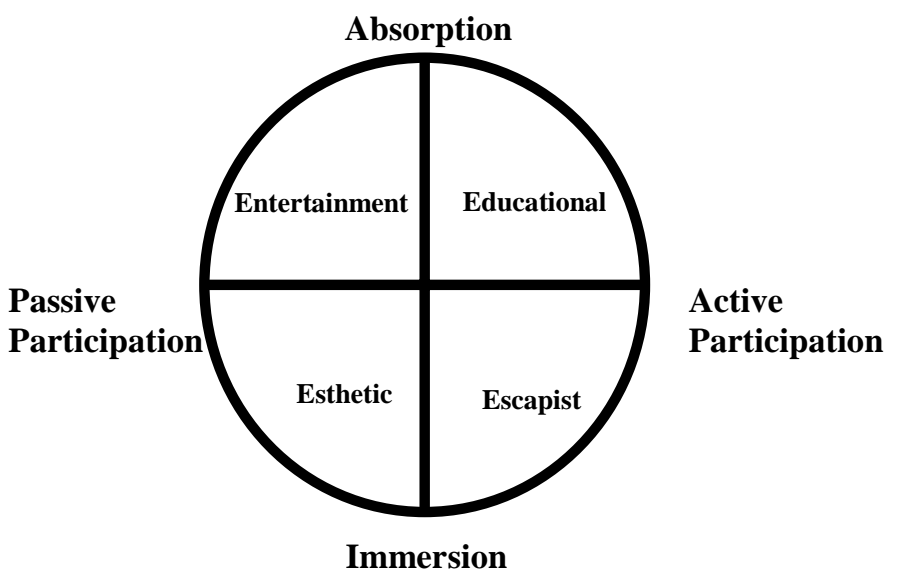

Figure 1. The four Realms of an Experience (Pine \& Gilmore, 1998)

By classifying the characteristic of customer participation, management can simplify to develop product strategies in order achieving the memorable experience for its customer and benefits to the companies.

\section{Methodology}

This research use qualitative descriptive research methods with the orientation of research object purposing. Researchers are the most important instrument in qualitative research. Qualitative analysis research method used to conduct the dimensional experience economy concept in village tourism. This research use observations (video tapping, and photo taking), interview (direct interview with recorder and phone interview), and documentation study as a data collection method. Research located at three different Regency in Bali: Bedulu tourism village in Gianyar, Buahan tourism village in Bangli and Taman Sari Buwana tourism village in Tabanan. Through the varieties location selected it might strengthen the validation of findings. 


\section{Results and Discussion}

Based on data collected in three tourism village activities (Bedulu tourism village, Buahan tourism village, and Taman Sari Buwana tourism village), it describe below:

Table 1. The Results of Data Collection Method

\begin{tabular}{|c|c|c|c|}
\hline $\begin{array}{l}\begin{array}{r}\text { Bali } \\
\text { Teurism } \\
\text { Villages }\end{array} \\
\text { Experience } \\
\text { Economy } \\
\text { Dimensions }\end{array}$ & $\begin{array}{l}\text { Bedulu } \\
\text { Tourism } \\
\text { Village } \\
\text { (Gianyar } \\
\text { ) }\end{array}$ & $\begin{array}{l}\text { Buahan } \\
\text { Tourism } \\
\text { Village } \\
\text { (Bangli) }\end{array}$ & $\begin{array}{l}\text { Taman } \\
\text { Sari } \\
\text { Buwana } \\
\text { Tourism } \\
\text { Village } \\
\text { (Tabanan } \\
\text { ) } \\
\end{array}$ \\
\hline Educational & $\begin{array}{l}\text { See the } \\
\text { local } \\
\text { communi } \\
\text { ty daily } \\
\text { routines } \\
\text { on } \\
\text { villages. }\end{array}$ & $\begin{array}{l}\text { See the } \\
\text { local } \\
\text { communi } \\
\text { ty daily } \\
\text { routines } \\
\text { on } \\
\text { villages. }\end{array}$ & $\begin{array}{l}\text { See the } \\
\text { local } \\
\text { communit } \\
\text { y daily } \\
\text { routines } \\
\text { on } \\
\text { villages. }\end{array}$ \\
\hline Escapist & $\begin{array}{l}\text { Balinese } \\
\text { cooking } \\
\text { class } \\
\text { practice, } \\
\text { Balinese } \\
\text { dancing } \\
\text { class } \\
\text { practice, } \\
\text { learn to } \\
\text { play } \\
\text { gamelan } \\
\text { instrume } \\
\text { nt, learn } \\
\text { to make } \\
\text { offerings, } \\
\text { pottery, } \\
\text { eggs } \\
\text { painting } \\
\text { arts, } \\
\text { teach } \\
\text { foreign } \\
\text { language } \\
\text { to local } \\
\text { children, } \\
\text { and Rice } \\
\text { field } \\
\text { nature } \\
\text { tracking } \\
\text { tour. }\end{array}$ & $\begin{array}{l}\text { Harvestin } \\
\mathrm{g} \text { fruits } \\
\text { and } \\
\text { vegetable } \\
\text { s, fishing } \\
\text { at lake } \\
\text { Batur, } \\
\text { Farm and } \\
\text { village } \\
\text { bike } \\
\text { tracking } \\
\text { tour. }\end{array}$ & $\begin{array}{l}\text { Rice field } \\
\text { farming } \\
\text { by buffalo } \\
\text { riding } \\
\text { ('Metekap } \\
\text { ') and } \\
\text { planting } \\
\text { rice, } \\
\text { making } \\
\text { offerings } \\
\text { (klatkat, } \\
\text { klangsah, } \\
\text { and tipat) } \\
\text { in local } \\
\text { village } \\
\text { house, } \\
\text { teach } \\
\text { foreign } \\
\text { language } \\
\text { to local } \\
\text { children, } \\
\text { Balinese } \\
\text { cooking } \\
\text { class } \\
\text { practice, } \\
\text { Village } \\
\text { and rice } \\
\text { field } \\
\text { nature } \\
\text { tracking. }\end{array}$ \\
\hline Esthetic & $\begin{array}{l}\text { Visit } \\
\text { 'Goa } \\
\text { Gajah' } \\
\text { heritage } \\
\text { site, Yeh }\end{array}$ & $\begin{array}{l}\text { See the } \\
\text { natural } \\
\text { scenery } \\
\text { of lake } \\
\text { and }\end{array}$ & $\begin{array}{l}\text { See the } \\
\text { natural } \\
\text { scenery of } \\
\text { rice field. }\end{array}$ \\
\hline
\end{tabular}

http://ojs.unud.ac.id/index.php/eot

\begin{tabular}{|c|c|c|c|}
\hline & $\begin{array}{l}\text { Pulu } \\
\text { carving } \\
\text { site, } \\
\text { Gedong } \\
\text { Arca } \\
\text { houses } \\
\text { (Bedulu } \\
\text { Museum) } \\
\text {, see the } \\
\text { natural } \\
\text { scenery } \\
\text { of rice } \\
\text { field. }\end{array}$ & $\begin{array}{l}\text { mount } \\
\text { Batur }\end{array}$ & \\
\hline $\begin{array}{l}\text { Entertainme } \\
\text { nt }\end{array}$ & $\begin{array}{l}\text { Watching } \\
\text { Kecak } \\
\text { Dance. }\end{array}$ & - & $\begin{array}{l}\text { Watching } \\
\text { traditional } \\
\text { dance by } \\
\text { locals. }\end{array}$ \\
\hline
\end{tabular}

Figure 2 below shows that, Bedulu tourism village varies in tourist participation activities. The cultural tourism product or activities of Bedulu tourism village dominate by the actives tourist's participation (Escapist and entertainment).

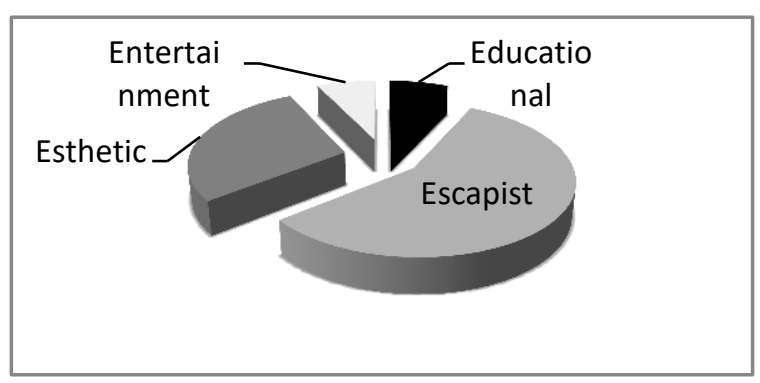

Figure 2. Bedulu Tourism Village Activities

Figure 3 below shows that, Buahan tourism village lack of activities variation. It indicates of zero activities of entertainment in Buahan tourism village. However, the cultural tourism product or activities of Buahan tourism village still dominate by the actives tourist's participation (Escapist).

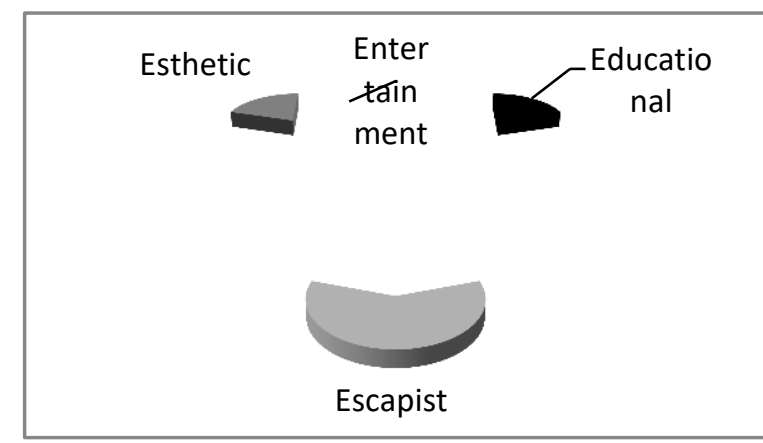

Figure 3. Buahan Tourism Village Activities 
Figure 4 below shows that, Taman Sari Buwana tourism village varies in tourist participation activities. The cultural tourism product or activities in Taman Sari Buwana tourism village dominate by the actives tourist's participation (Escapist and Entertainment).

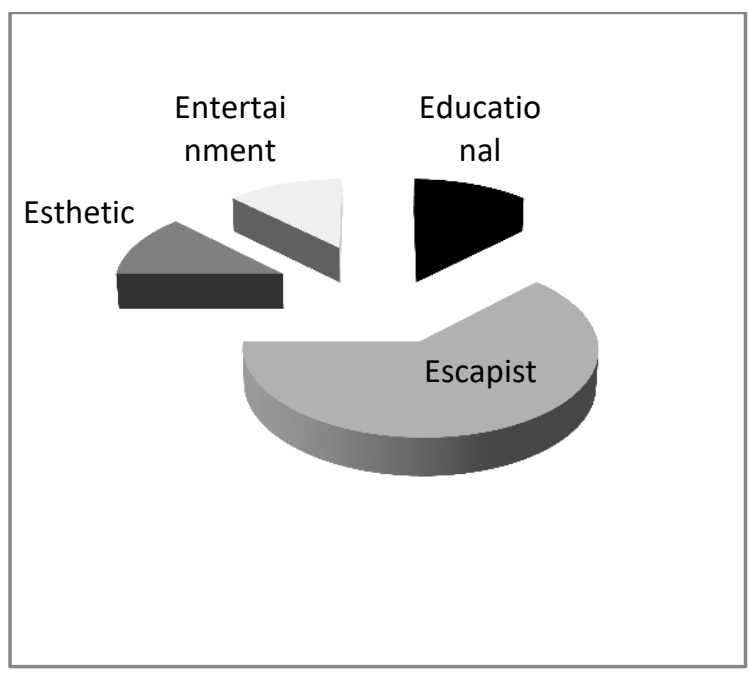

Figure 4. Taman Sari Buwana Tourism Village Activities

Cultural tourism is not only for shown, but there also must be tourist participation and experience (Stevensons, 2003; cited in Wearing, Stevenson and Young, 2009). In this cultural tourism village case, results that the active participation activities is greater than the passive participation activities. It means that, the memorable experience could be able to achieve by implementing tourism village concept on cultural tourism destination. (Richardson and Fluker, 2004) stated that, cultural tourism offers personal contact with local people and those who have special knowledge of interesting features. Tourists who travel to tourism village have possibility motivated by their cultural needs. They travel by purpose, to gain knowledge and experience of different culture. Richards (2001) stated that, tourists are not just interest in the sights of modernity, but they want the sounds, smells, taste and touch a culture.

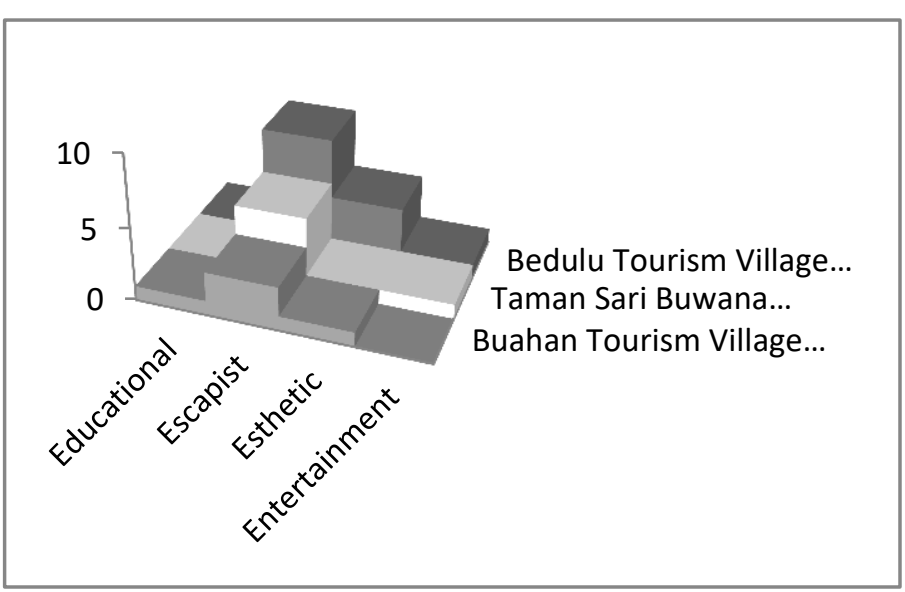

Figure 5. The Comparisons of Tourism Village Activities

Figure 5 above illustrate the level of cultural tourism product through the activities of three tourism village (Bedulu tourism village, Taman Sari Buwana tourism village, and Buahan tourism village). Among the three tourism village, Bedulu tourism village has most product or activities variations, and Buahan tourism village has the less product or activities variations.

To improve the cultural product or activities through participations, Stasiak (2013) elaborate the intensifying tourist thrills and emotions methods, such as: (1) transforming the tourism infrastructure to offer unique tourist attraction; (2) expanding older forms of a tourism product by elements of experience and emotion; (3) creating a socalled 'augmented reality', new forms of recording tourism experience and sharing it; (4) discovering new tourism spaces, to provide unique, sometimes extreme experience; (5) developing new forms of tourism to provide original, extraordinary emotions and develop the tourists' skills, creativity and personality.

\section{Conclusion and Recommendation}

\section{Conclusion}

Based on the study above, it concluded that the experience economy on the approach of 4E's (Educational, Escapist, Esthetic and Entertainment) perceived differently by tourists. It depending on (1) the kinds and the types of activities offered by the tourism village, (2) The extent to which the involvement of tourists in activity are packaged in the tourism village. 
The more memorable tourist experience that is felt on the activities undertaken, it is increasingly given the memory of them. Value memories (memorable experience) justified the tourists to pay higher prices. Experience economy positively in accordance with how much it paid. In tourism means, the greater memorize their tourism experience the greater the tourism companies sustain in the global market competition.

\section{Recommendation}

The management of tourism village should consider the 4E's aspects equally in combining (packaging) the cultural tourism product or activities. Therefore, the purpose of memorable experience could be achieved.

\section{References}

Ardika, I. G. (2011) 'Wisata Desa, Konsep dan Pengembangannya'.

Bille, B. and Business, C. (2010) 'The Nordic approach to the Experience Economydoes it make sense?', Policy, 18(1), pp. $93-110$.

Ju, H. (2014) 'Study on urban tourism development based on experience economy in Shanghai', International Journal of Business and Social Science. Centre for Promoting Ideas, USA, 5(4).

Leslie, D. and Sigala, M. (2005) International cultural tourism: Management, implications and cases. Routledge.

Page, S. J. et al. (2001) Tourism: A Modern Synthesis. London: Thomson Learning.

Picard, M. (1996) Bali. Cultural tourism and touristic culture. Archipelago Press.

Pine, B. J. and Gilmore, J. H. (1998) 'Welcome to the experience economy', Harvard business review, 76, pp. 97-105.

http://ojs.unud.ac.id/index.php/eot
Pine, B. J. and Gilmore, J. H. (2011) The experience economy. Harvard Business Press.

Pine II, J. and Gilmore, J. (1999) The experience economy. Boston: Harvard Business School Press.

Richards, G. (2001) Cultural attractions and European tourism. Cabi.

Richards, G. (2007) Cultural Tourism: Global and local perspectives. Psychology Press.

Richardson, J. I. and Fluker, M. (2004) Understanding and managing tourism. Pearson Education Australia.

Stasiak, A. (2013) 'Tourist product in experience economy', Tourism. De Gruyter Open, 23(1), pp. 27-36.

Wearing, S., Stevenson, D. and Young, T. (2009) Tourist cultures: Identity, place and the traveller. Sage. 